\title{
Institutional Ownership and Disclosure of Forward-Looking Information: Evidence From Egypt
}

\author{
Eman M. Saad Eldeen \\ Professor of Accounting, Accounting Dept. \\ Beni Suef University, Egypt \\ E-mail: emaneldeen2005@hotmail.com
}

Received: September 30, 2019 Accepted: October 25, 2019 Published: November 3, 2019

doi:10.5296/ijafr.v9i4.15544

URL: https://doi.org/10.5296/ijafr.v9i4.15544

\begin{abstract}
The main objective of this study is to investigate the relationship between institutional ownership (IO) and the extent of forward-looking information (FLI) disclosure, by companies listed in the Egyptian Stock Exchange (ESE) for the year 2017. A sample comprising 34 companies was chosen from the most active 50 Egyptian listed companies in the ESE. To attain study objective, an index comprises 23 financial and non-financial items has been developed to measure disclosure level by sample companies. The descriptive analysis reveals a weak disclosure of future information by Egyptian listed companies ranging from 0.17 to 0.58, which indicates high variation in future disclosure among sampled companies. Moreover, the correlation analyses shows a positive strong significant correlation between the future looking disclosure level and institutional ownership, and also a positive moderately significant correlation between future looking disclosure and both audit firm and firm age. However, there is no significant correlation between future information disclosure and both firm size and industry type.
\end{abstract}

Keywords: Forward Looking Information (FLI), Institutional ownership, Future disclosure guidelines, Egyptian listed companies

\section{Introduction}

Future disclosure has been one of the most recent accounting issues, especially in developing countries like Egypt. In these countries, capital markets development and efficiency rely heavily on decreasing information asymmetry between controlling shareholders and minority outsiders. Some studies (e.g. Dhaliwal, 2011; Hussainey \& AL-Najjar, 2011) suggest that Disclosure of forward- looking information (FLI) in the annual reports may reduce the degree 
of information asymmetry between managers and investors.

Recently, many accounting bodies and professional agencies have shown a lot of interest to specify future disclosure motives, components and methods. As mentioned by Beyer et al. (2010), management forecasts and disclosures provide both investors and financial analysts with financial as well as non-financial information; to enable them to make rational investing decisions and build financial forecasts. Moreover, the literature indicates that financial information focuses on financial performance reporting, whereas non-financial disclosure involves firm strategy, uncertainties and risks (e.g. Celik et al., 2006; Aljifiri and Hussainey, 2007; Menicucci, 2013; Alkhatib, 2014). In addition, looking-forward information is sort of voluntary disclosure concerning future forecasts which enable users to evaluate company's future performance (Menicucci, 2013).

Most prior studies focused on the percentage of shares held by institutional investors and the concentration of their ownership on quality of disclosure (for instance, Jiang et al., 2011; Boone and White, 2015; Yasser et al., 2016; Hsu et al., 2016; Shiri et al., 2016). However; the effect of institutional investors on FLI disclosure level has been overlooked. This study tries to fill this gap by testing the influence of institutional ownership on disclosing future information. This is the first empirical study - to the best of my knowledge- carried out in Egypt as one of the emerging market regarding this issue. Additionally, there is a lack of guidance, releases or standards which can regulate future - oriented information which, in turn, leads to a variety of disclosure levels between listed companies.

It was found that although many studies on FLI have been conducted, the empirical investigation about the relation between FLI and IO in the Egyptian environment is limited. The lack of empirical studies concerning this issue is the main factor that motivated the author to undertake this study. It was aimed that the study will guide users to understand FLI disclosure in Egypt.

The main objective of this study is to investigate the relationship between institutional ownership and the extent of forward-looking information disclosure, by companies listed on the Egyptian Stock Exchange (ESE) for the year 2017. Institutional investors are widespread in the market, taking over high rate of trading volume in the exchange, in addition to a lack of sufficient releases and legislations to protect minority shareholders.

The remainder of this paper is organized as follows: Section 2 provides a background about Egypt. Section 3 shows the need for FLI in Egypt. Section 4 reviews the related literature and indicates hypotheses development. Section 5 shows research methodology including data and sample selection procedure. Section 6 presents results of the study. Section 7 summarizes the main conclusion and recommendations of the study.

\section{Background About Egypt}

Egypt is an Arabian country located in North Africa and has played an important role in forming the Middle East polices for decades. Egypt is a unique developing country because in the early 1990's one of the oldest stock exchange (EGX) was established (Note 1) (Abdel Shahid, 2003). Since early 1990's, the Egyptian government has started an ambitious 
economic reform towards free market economy. To activate the market, the government started offering state-owned companies to the public through the privatization program (Cairo \& Alexandria Exchange, 2007). The Egyptian government has frequently announced the need to attract foreign investments to the Egyptian market which, in turn, requires high level of financial disclosure. As a result, Egyptian firms may increase voluntary disclosure level; so as to support market value of their stocks and retrieve national and foreign trustworthy (Samaha and Abdallah, 2011).

Moreover, a new investment law no. 72 has been issued in May 2017 by Ministry of International Cooperation and Investment, aiming at attracting foreign and Arab investment to Egypt. It is expected that the new law may remove restrictions imposed on foreign investments, enabling foreign investors to fully enjoy market access and to freely transfer their dividends abroad.

Egyptian Listed Companies have adopted corporate governance (CG) mechanisms since 2005; in addition to strict disclosure rules according to the Egyptian accounting standards. The Egyptian standards are convergent with International Financial Reporting Standards (IFRS) and were updated in July 2015. This is to ensure a high quality of disclosure and transparency of published financial reports.

\section{The Need for FLI in Egypt}

Surprisingly, there is no Egyptian accounting guideline to motivate listed companies to disclose FLI in their annual reports. Anyhow, The Central Accountability Agency (CAA) has issued an Egyptian Auditing Standard No. (3400) in 2008, entitled "Testing Prospective Financial Information". This standard aims at providing some guidance for auditors when inspecting future financial information; so as to reach to the best theoretical estimates (CAA, 2008).

The Egyptian Financial Supervisory Authority (EFSA) issued rule no. (31) in 2011; to amend listing and delisting rules to force Egyptian listed companies to quarterly report shareholders' and board of directors' ownership structures. This disclosure encompasses shareholder who owns $5 \%$ or more in a separate line, in addition to total number of shares owned by board members and ownership percentage (EFSA, 2011). Recently, the EFSA released rule no. (11) in 2014, which was amended in 2016; to emphasize that listed company should accompany the disclosure report with a study approved by financial consultant. This study should include future financial prospective and future expectation about profitability; and whether the company's financial resources are sufficient to achieve it (EFSA, 2016a).

Moreover, The Egyptian code of corporate governance (ECCG) issued in 2005 and amended twice in 2011 and 2016 (EFSA, 2016b), has confirmed future performance disclosure. It indicated that companies should disclose financial and non-financial information (e.g. company vision, future plans, strategies and risks); so as to increase disclosure and transparency in financial reporting. Additionally, the company should issue management discussion and analysis (MD \& A) report encompassing current as well as future projects and investments. 
In short, Egyptian regulators have taken slow steps towards narrative future disclosure, although there is an absence of standards or guidelines which, in turn, contributed to a variation in disclosure level in practice.

\section{Literature Review and Hypothesis Development}

Institutional investors are defined as large investors like banks, mutual funds, pension funds, insurance companies and financial institution which invest high percentage in equity and have a great impact on companies' activities; since they can monitor managers (Velury \&Jenkins, 2006)

The question to whether institutional investors contribute to better manage and monitor the business is still controversial. Some studies (e.g Jung \& Kwon, 2002; Zhang and Ding, 2006; Velury \& Jenkins, 2006; Huafang and Jiangguo, 2007; Choi \& Seo, 2008; Johari et al,. 2016; Buchanan, et al., 2018 ) argue that institutional owners possess great impact and power to actively manage and control the business; due to their large investment and expertise. Consequently, such type of ownership may lead to an increase in financial disclosure quality, earning informativeness and a decrease in earning management and financial leverage (Mazumder, 2016; Sakaki et al., 2017; Cinko and Kasaboglu, 2017). Conversely, other studies (e,g, Hossain et al., 2006; Jiang, 2009; Burns et al., 2010; Jiang, 2011; Sahin, 2011; Tsouknidis, 2019) discuss that institutions lack expertise and have access to information which may cause information asymmetry and a low quality of financial disclosure and transparency.

A number of previous studies have found that IO can improve corporate governance CG adoption. Chung and Zhang (2011) examined the relationship between the corporate governance variables and increasing ownership percentage of institutional investors in American listed companies. Their results revealed an increase in this percentage with the application of high quality CG. Moreover, Chan et al. (2007) examined the relationship between ownership structure and the quality of audit in China in which both governmental and institutional owners are dominant. They found that lower level of governmental owners versus higher level of institutional shares could lead to an increase in high quality audit services. Similar results were shown in Jordan by Zureigat (2011), who reported a positive and significant relationship between highly concentrated institutional investors and hiring big audit firm. Also, in Kuwait, Almutairi (2013) conducted a study to examine the effect of institutional ownership and firm debts on the quality of audit. He found a positive association between hiring industry specialized audit firm and both institutional ownership and company debt. Similarly, Chen et al. (2017) found that institutional investors supported the audit committee to appoint big audit firm which improved internal control and lower audit costs. The results indicated that Institutional investors engaged specialized audit firm; so as to improve financial reporting quality.

On the other side, the accounting literature indicated that IO may help to improve transparency and disclosure. Choi and Seo (2008) investigated the relationship between institutional investors and transparency in financial reports of Korean companies. Their results revealed a significant positive relation between IO and accounting transparency level in financial reporting. The study also found that IO may limit earning management in the 
accounting records related to financial, investing and operating activities. Boone and White (2015) investigated the impact of IO on both trading environment and information transparency. They concluded that IO is positively associated with higher financial disclosure and decreased information asymmetry and trading costs. Similar results were revealed by Hsu et al. (2016) who pointed out that high percentage of domestic IO in high- tech industries is reflected in an increase in information transparency. Also, Cheng et al., (2018) found that transient institutional investors strongly supported stock returns and prices during market recession.

Mazumder (2016) reported that higher institutional ownership is positively associated with earning predictability in Japanese listed companies. Furthermore, IO enhanced high quality of financial reporting. Also, Velury and Jenkins (2006) examined the relationship between IO and financial reporting quality. They found that IO is positively and significantly affect the quality of earnings. In Iran, Mehrani et al. (2017) found significant and positive association among IO and high earnings quality. Similar results were reached by Yasser et al. (2016) who examined the relationship between ownership structure and quality of financial reporting in Asia-Pacific region. The results indicated that Institutional as well as foreign ownership are associated with improved financial disclosure in developing countries.

On the contrary, Shiri et al. (2016) investigated the influence of both ownership structure and financial reporting quality on information asymmetry in Iranian listed companies. The results showed that information asymmetry increased with higher IO and decreased when highly reliable and timely financial reports are issued. They explained that institutional investors have incentives to keep private information to their own commercial benefits. Jiang et al. (2011) added that institutional investors are less keen to monitor management which may increase agency problems. Moreover, Tsouknidis (2019) reported that institutional investors contributed to a low performance of US listed shipping companies. He traced this finding to non-strategic institutional investors and market recessions.

Concerning accounting disclosure of future looking information, a number of prior studies reported contradicting results. Celik et al. (2006) concluded that future disclosure level is negatively associated with institutional investors and profitability. They examined factors which affected FLI disclosure level in Istanbul listed companies. On the contrary, Mathuva (2012) found a positive influence of Institutional investors, profitability and leverage on future disclosure level of listed Nairobi companies. Also, Krause et al. (2017) found a high quantity future disclosure by German listed companies during the crises, but at a low quality due to uncertainty.

Moreover, Aljifri and Hussainey (2007) conducted a study to specify factors which influence future disclosure of companies listed in Dubai Stock Exchange. They indicated that both profitability and debt ratio have a significant effect on disclosure level. They added that audit size and industry type have no significant effect on future disclosure level. Also, Alkuliti (2011) investigated company's characteristics which affect future disclosure level in Egyptian listed companies during 2010. He reported that size, debt ratio and profitability are positively associated with LFI disclosure level, whereas ownership dispersion, age and audit firm have 
no effect. Correspondingly, Baroma (2013) found that auditor type has a positive significant impact on FLI disclosure level in Egyptian listed non-financial firms, whereas industry type has no significant effect. Further, Alkhatib (2014) revealed that high profitable companies were concerned with disclosing more future information. Also, Mousa and Elamir (2018) concluded that financial leverage and firm size were found to be significant on FLI disclosure level. However; liquidity, profitability and industry type were insignificant.

On the other hand, in China, Liu (2015) examined the relation among CG mechanisms and forward - looking disclosure. The study concluded that good governance characteristics, such as financial expertise in audit committee, independency of board members and foreign ownership can increase FLI disclosure level. Also, Elgammal et al. (2018) found that Quatari firms with high foreign ownership disclosed more FLI, whereas board size negatively affected the disclosure level. In addition, Wang and Hussainey (2013) indicated that forward-looking statements published by good governance firms contribute to stock market's ability to predict future earnings. Similarly, Qu et al. (2015) reported a positive influence between strict $\mathrm{CG}$ application and disclosing accurate future sales as well as non -financial information. Also, Al-Najjar and Abed (2014) concluded that board independence and size are positively associated with high level of FLI disclosure. Bravo (2016) added that high and good reputation companies are well motivated to disclose more FLI which contributed to reduce stock volatility and cost of capital.

In light of various results drawn from previous studies, I can differentiate the current study from earlier related research in many aspects. First, previous studies provided contradictory findings concerning the relationship between IO and voluntary disclosure level. Second, there was no direct study investigated the effect of IO on forward looking disclosure. Accordingly, there is a need to examine this issue further especially in emerging markets like Egypt, in which high ownership concentration is dominant in listed companies. Also most listed companies are owned and controlled by few investors mainly: institutional investors, controlling families and managerial. Institutional investors include four main types as follows: insurance companies, banks, investing companies and mutual funds. Therefore, the current study aims to fill in this gap in the accounting literature. Second, most of the previous studies are conducted in developed countries; and very little is known about emerging economies; and Egypt is no exception.

To attain study objective about the relationship between institutional investors and FLI, the study has relied on both the literature review and theoretical background to formulate the research hypothesis as follows:

Hypothesis 1: There is no statistically significant effect of institutional ownership percentage on FLI disclosure level by Egyptian listed companies.

\section{Research Methodology}

\subsection{Data Collection, Sample Selection and Data Analysis}

In this section an empirical study is conducted using content analysis approach to identify future disclosure by institutional listed firms in ESE during the year 2017. The data to 
measure study variables was manually collected from sampled companies' annual reports and official websites. The used sample is based on the most active fifty companies listed in the ESE during the year 2017. Those companies are deemed to have more disclosure and transparency; since they are subject to strict monitoring and controlling by EFSA. An initial sample of the study comprises 38 (76\%) Egyptian companies excluding financial institutions. They follow special regulations issued by The Central Bank of Egypt and Basel requirements. Anyhow, the final sample consists of 34 Egyptian listed companies after eliminating four companies; due to suspension and incomplete data. It should be also noted that IO in sample companies are highly concentrated (i.e. $25 \%$ or more) following some prior studies (e.g. Anderson and Reeb, 2003; Chau and Leung, 2006; Chau and Gray, 2010).

\subsection{Measuring the Dependent Variable (FLI Disclosure Index)}

In fact there are no general guidelines; so as to measure the extent of FLI disclosure level. Accordingly, a proposed disclosure index was developed relying on prior literature (e.g. celik et al., 2006; Chau \& Gray, 2010; Alkulaiti, 2011; Saad Eldeen, 2014; Al-Najjar and Abed, 2014; Liu, 2015; Mousa and Elamir, 2018), the Egyptian manual of CG and actual observations as shown in financial reports of Egyptian companies. The checklist comprises 23 items in three groups and is equally weighted (See appendix A). So as to measure disclosure level, a dichotomous approach was applied whereby a company was assigned " 1 " if the item was disclosed and " 0 " otherwise. The FLI disclosure level was calculated as the ratio of total items disclosed by specific company divided by the maximum number of information items.

\subsection{Measuring the Independent Variable}

The independent variable included in the study is concentrated institutional ownership (25\% or more) which will be measured as percentage of shares held by institutional investors in sample companies.

\subsection{Measuring the Control Variables}

The study incorporates four control variables to the regression model which are as follows: firm size, audit firm, firm age and industry type. Firm size is measured by the natural logarithm of book value of total assets. Audit firm is a dummy variable which took " 1 " if the auditor was one of the big 4 or " 0 " otherwise. The firm age is defined by the log of years; since the firm was established till the year 2017. The industry type is a dummy variable that assigned " 1 " if the firm is manufacturing or " 0 " otherwise.

\subsection{Model Development}

To investigate the relationship between institutional investors and FLI disclosure level by Egyptian listed companies, the following multiple regression model is used:

$$
\text { FLIDL }=\beta 0+\beta 1 \text { INSOWN }+\beta 2 \text { FSIZE }+\beta 3 \text { AUDIT }+\beta 4 \text { FAGE }+\beta 5 \text { ITYPE }+\varepsilon
$$

Where:

FLIDL $=$ extent of forward - looking disclosure scores 
INSOWN = proportion of institutional ownership

FSIZE $=$ firm size

AUDIT $=$ type of audit firm

$\mathrm{FAGE}=$ firm age

ITYPE = industry type

$\varepsilon=$ error term

\section{Results}

\subsection{Descriptive Statistics}

Table 1 below shows the result of the descriptive statistics test of the dependent variable, independent variables and control variables:

Table 1. Descriptive statistics

\begin{tabular}{llllll}
\hline & $\mathrm{N}$ & Minimum & Maximum & Mean & Std. Deviation \\
\hline FLIDL & 34 & .17 & .58 & .3909 & .10306 \\
\hline INSOWN & 34 & .34 & .93 & .6885 & .16930 \\
\hline FSIZE & 34 & 174284372 & 73119438572 & 6953209469.44 & 13903524907.561 \\
\hline FAGE & 34 & 16 & 105 & 48.09 & 22.791 \\
\hline
\end{tabular}

The first column labeled $\mathrm{N}$, represents the number of companies, which equals 34 companies for all variables. The average of "extent of forward-looking disclosure scores (FLIDL)", of the sample companies, was 0.39 , with a range of 0.17 to 0.58 , with a low standard deviation equals to 0.1. Thus, the results indicated a high variation in future disclosure practices between the sample companies, and also revealed that this disclosure is quite poor (a mean score of 39\%) compared with similar companies in developed countries. As Al-Najjar and Abed (2014) found that FLI disclosure of the listed companies in UK exceeded (94\%).

From the author point of view the main reason can be traced to the fact that FLI disclosure is still voluntary, and there is no accounting guidelines or standards issued in Egypt to regulate such information.

The average of "proportion of institutional ownership (INSOWN)", of the sample companies, was 0.69 , with a range of 0.34 to 0.93 , with a low standard deviation equals to 0.16 . It can be emphasized that institutional investors are highly concentrated in the Egyptian companies. Regarding the company size (FSIZE), the sample companies have average total assets of 6953209469.44 L.E., with a range of 174284372 to 73119438572 L.E. Additionally, the above table shows that the average of "firm age (FAGE)" of the sample companies was 48.09 
year, with a range of 16 to 105 year, with a standard deviation equals to 22.8 year. This indicates that the majority of companies had been working in the Egyptian market for a long time period.

\subsection{Correlations}

Table 2 below provides the Pearson correlations of the dependent and independent variables. The results show that there is a strong positive significant correlation between the dependent variable (FLIDL) and independent variable (INSOWN) which is 0.95 . In addition, there is a positive moderately significant correlation between the dependent variable (FLIDL) and both AUDIT and FAGE which are 0.4, 0.57 respectively. This findings support the argument that audit firm may induce their clients to disclose high quality future information which exceeds accounting standards requirements; to increase transparency and enhance trust of financial reporting users. Similar results were reported by some prior studies (Almulairi,2013; Baroma,2013; Alkhatib,2014; Chen et al., 2017). In addition, companies with long time period of listing in the ESE have enough information for a long time period which facilitates prediction of future performance and profitability, compared with newly listed companies. Moreover, they want to send a message to the market about the quality of their companies, to limit information asymmetry and to reduce agency conflicts. This result is inconsistent with some previous studies (e.g. Soliman 2013; Alkulaiti, 2011). However, in this study, there is no significant correlation between (FLIDL) and (FSIZE). This result agrees with some previous studies (Celik et al., 2006; Aljifri and Hussainey, 2007; Menicucci, 2013) which reported an insignificant association between future disclosure and company size. This result confirms the assumption that big companies believe that disclosing future information could badly harm their future plans and, in turn, lose their competitive advantage. Furthermore, industry type does not seem to be significant in investigating the level of future information disclosure for the sample companies. The result is consistent with other previous studies that found no significant correlation between industry type and future disclosure level (e.g. Aljifri and Hussainey, 2007; Alkulaiti, 2011; Baroma, 2013; Mousa and Elamir, 2018). Also, there is positive moderately significant correlations between INSOWN and both AUDIT and FAGE which are $0.48,0.6$ respectively. Finally, there is a positive moderately significant correlation between AUDIT and FAGE which is 0.33 .

Table 2. Pearson correlations

\begin{tabular}{|c|c|c|c|c|c|c|c|}
\hline & & FLIDL & INSOWI & FSIZE & AUDIT & FAGE & ITYPE \\
\hline \multirow[t]{5}{*}{ Pearson Correlation } & FLIDL & 1.000 & & & & & \\
\hline & INSOWN & .947 & 1.000 & & & & \\
\hline & FSIZE & .064 & .067 & 1.000 & & & \\
\hline & AUDIT & .401 & .482 & .173 & 1.000 & & \\
\hline & FAGE & .566 & .602 & .186 & .333 & 1.000 & \\
\hline
\end{tabular}




\begin{tabular}{llllllll}
\hline & ITYPE & $-.090-$ & $-.028-$ & $-.066-$ & $-.099-$ & .015 & 1.000 \\
\hline Sig. (1-tailed) & FLIDL &. & & & & \\
\cline { 2 - 7 } & INSOWN & .000 &. & & & \\
\hline & FSIZE & .359 & .353 &. & & \\
\hline AUDIT & .009 & .002 & .163 &. & \\
\hline FAGE & .000 & .000 & .146 & .027 &. \\
\hline
\end{tabular}

The adjusted coefficient of determination (Adjusted R Square) of the model in Table 3 indicates that $89.3 \%$ of the variation in the dependent variable (FLIDL) is explained by variations in the independent and control variables (Anderson,2011). The ratio is very high which confirms the efficiency of the model.

Table 3. Adjusted R Square

\begin{tabular}{llll}
\hline Model & $\mathrm{R}$ & R Square & Adjusted R Square \\
\hline 1 & $.947^{\mathrm{a}}$ & .897 & .893 \\
\hline
\end{tabular}

\subsection{F Test}

As presented in Table 4 the multiple regression model reported an F value of 277.214 ( $\mathrm{p}<$ 0.000 ) for the level of disclosure which statistically supports the significance of the model.

Table 4. ANOVA ${ }^{\mathrm{a}}$

\begin{tabular}{lllllll}
\hline \multicolumn{2}{l}{ Model } & \multicolumn{2}{l}{ Sum } & of & & \\
Squares & df & Mean Square & F & Sig. \\
\hline 1 & Regression & .314 & 1 & .314 & 277.214 & $.000^{\text {b }}$ \\
\cline { 2 - 7 } & Residual & .036 & 32 & .001 & & \\
\cline { 2 - 6 } & Total & .350 & 33 & & & \\
\hline
\end{tabular}

a. Dependent Variable: FLIDL

b. Predictors: (Constant), INSOWN

\subsection{Results of Regression Model}

Table 5 provides the results of the OLS regression for the model using the stepwise method. The regression model indicates that there is a positive significant effect of institutional ownership percentage on FLI disclosure level of Egyptian listed companies. This finding 
suggests that Egyptian firms with high percentage of institutional ownership disclose more FLI. This results is consistent with that reached in many prior studies (e.g. Mathuva,2012; Yasser et al., 2016; Mazumder,2016; Hsu et al., 2016; Mehrani et al.,2017; Cheng et al., 2018). This result enhances the discussion that institutional investors own enough skills and resources; so as to publish future information in annual reports, and to enhance their competitive advantage. Moreover, foreign investors and financial analysts price such information to evaluate companies' future financial performance. However, there is no statistically significant effect of FSIZE, Audit, FAGE, and ITYPE on FLIDL.

Table 5. Coefficients

\begin{tabular}{|c|c|c|c|c|c|c|}
\hline \multirow[b]{2}{*}{ Model } & \multicolumn{2}{|c|}{$\begin{array}{l}\text { Unstandardized } \\
\text { Coefficients }\end{array}$} & \multicolumn{2}{|l|}{$\begin{array}{l}\text { Standardized } \\
\text { Coefficients }\end{array}$} & & $\begin{array}{l}\text { Collinearity } \\
\text { Statistics }\end{array}$ \\
\hline & B & $\begin{array}{l}\text { Std. } \\
\text { Error }\end{array}$ & Beta & $\mathrm{t}$ & Sig. & VIF \\
\hline 1 (Constant) & $-.006-$ & .025 & & -.243 & .809 & \\
\hline INSOWN & .576 & .035 & .947 & 16.650 & .000 & 1.000 \\
\hline
\end{tabular}

Multicollinearity in explanatory variables has been diagnosed through Variable Inflation Factors (VIF). The (VIF) in excess of 10 should be considered an indication of harmful multicollinearity (Ewart et al., 1982). Alternatively, if the average VIF is substantially greater than 1 , then the regression may be biased. Table 5 shows that the average of VIF is (1.000). Consequently, this confirms that collinearity is not a problem for this model. These findings suggest that multicollinearity between the independent variables is unlikely to pose a serious problem in the interpretation of the results of the multivariate analysis.

As a result, the null hypothesis is rejected and the alternative hypothesis which indicates a positive significant effect of INSOWN on FLIDL is accepted; since study findings support this hypothesis. Additionally, there is a positive significant association between FLIDL and both AUDIT and FAGE.

\section{Conclusion, Limitations and Future Research}

This study is mainly concerned with the effect of institutional controlled firms and the extent of future looking information disclosure by Egyptian listed companies. Over the last decade, there has been a stream of research concerning the effect of concentrated ownership on voluntary disclosure. Institutional investors are widespread in the Egyptian market, taking over high rate of trading volume in the exchange. FLI is considered to be one of the most recent accounting disclosures directed towards improving financial markets efficiency. To attain the study objective, an empirical study has been conducted for a sample comprising (34) Egyptian listed Institutional firms during the year 2017. Relying on prior literature, an index comprising (23) financial as well as nonfinancial items has been developed; so as to measure 


\section{Ml Macrothink}

International Journal of Accounting and Financial Reporting

ISSN 2162-3082

2019, Vol. 9, No. 4

FLI disclosure level by Egyptian companies. The author followed the inductive methodology and content analysis of the annual financial reports; to test the study hypothesis and data was analyzed by the statistical program (SPSS).

After reviewing the literature, the study model was developed to comprise one independent variable of institutional ownership and four control variables in the regression model. These variables are as follows: firm size, audit firm, firm age and industry type. Descriptive analysis reveals a weak practice by Egyptian listed companies regarding future disclosure ranging from 0.17 to 0.58 . This result indicates a high variation in future disclosure among sampled companies. This is because FLI disclosure is still voluntary and there is no accounting guidelines or standards issued in Egypt to regulate such information. Also, the results show that institutional ownership is highly concentrated in the Egyptian sampled companies ranging from 0.34 to 0.93 . Conversely, future disclosure is quite high in developed countries like listed companies in U.K. (Al-Najjar and Abed, 2014). Moreover, FLI disclosure is obligatory for German public companies and should be published in their annual reports (Krause et al., 2017).

The regression analyses show that Egyptian companies with a high percentage of institutional ownership disclose more future looking information. In addition, exploratory analysis highlights a positive moderately significant correlation between the future looking information disclosure and both audit firm and number years of listing the companies. However, there is no significant correlation between disclosure of future looking information and both firm size and industry type.

The study suffers from some limitations. First, the sample companies are restricted to 34 companies which were chosen from the most active listed companies during the year 2017. The sample seems to be small in size and may not represent the whole population; so results should be evaluated with caution. Second, the index of FLI is measured relying on unweighted checklist to avoid bias and incorporate 23 items. Third, the study includes one type of concentrated ownership; since institutional investors are widespread in the Egyptian market.

Future research may examine the impact of other types of concentrated ownership (e.g. family firms, foreign, managerial) on future looking information disclosure in other developing countries like GCC countries.

Moreover, regulatory Agency should issue some legislations that guarantee legal protection of management against accountability for financial forecasts, and preferably to include warning paragraph regarding expected risks that may cause variances between actual and expected performance. Big audit firms in Egypt should be encouraged to apply Egyptian standard No. (3400) about examining FLI and to issue a report; so as to increase its credibility for investors. Additionally, the Financial Control Agency and professional bodies could induce companies to increase voluntary disclosure in annual reports. This disclosure may decrease information asymmetry that exists between controlling owners and the minority shareholders. 


\section{References}

Abdelsalam, O., El Masry, A., \& Elsegini, S. (2008). Board composition, ownership structure and dividend policies in an emerging market. Managerial Finance, 34(12), 953-964.

Abdel-Shahid, S. (2003). Does ownership structure affect firm value? Evidence from the Egyptian stock market. Working Paper, Cairo and Alexandria Stock Exchange, Egypt. Retrieved from www.egyptse.com

Aljifri, K., \& Hussainey, K. (2007). The determinants of forward-looking information in annual reports of UAE Companies. Managerial Auditing Journal, 22(9), 881-894.

Alkhatib, K. (2014). The Determinants of Forward-Looking Information Disclosure. Procedia-Social and Behavioral Sciences, 109, 858-864.

Alkulaiti, I. (2011). The effect of entity' characteristics on-forward looking information disclosure level in annual reports of Egyptian listed companies. Journal of Accounting Thought, 2(2), 1-74.

Almutairi, A. (2013). The impact of institutional ownership and corporate debt on audit quality. Journal of Economic and Administrative Sciences, 26, 1-31.

Al-Najjar, B., \& Abed, S. (2014). The association between disclosure of forward-looking information and corporate governance mechanisms Evidence from the UK before the financial crisis period. Managerial Auditing Journal, 29(7), 578-595.

Anderson, D., Sweeny, D., Williams, T., Freeman, J., \& Shoesmith, E. (2011). Statistics for business and economics. International Edition, South-Western.

Anderson, R., \& Reeb, D. (2003). Founding-family ownership and firm performance. Journal of Finance, 58, 1301-1328.

Baroma, B. (2013). The impact of market-related variables on forward-looking disclosure in the annual reports of non-financial Egyptian companies. International Journal of Social, Management, Economics and Business Engineering, 7(6), 605-610.

Beyer, A., Cohen, D., Lys, T., \& Walther, B. (2010). The financial reporting environment: Review of the recent literature. Journal of Accounting and Economics, 50(2-3), 296-343.

Boone, A., \& White, J. (2015). The effect of institutional ownership on firm transparency and information production. White Journal of Financial Economics, 117, 508-533.

Bravo, F. (2016). Forward-looking disclosure and corporate reputation as mechanisms to reduce stock return volatility. Revista de Contabilidad - Spanish Accounting Review, $19,122-131$.

Buchanan, B., Cao, C., \& Chen, C. (2018). Corporate social responsibility, firm value, and influential institutional ownership. Journal of Corporate Finance. Retrieved from https://ssrn.com/abstract=3227157

Burns, N., Kedia, S., \& Lipson, M. (2010). Institutional ownership and monitoring: Evidence 
from financial misreporting. Journal of Corporate Finance, 4(16), 443-455.

Cairo and Alexandria Exchange. (2007). Yearbook. Egypt.

Celik, O., Ecer, A., \& Karabacak, H. (2006). Disclosure of forward looking information: Evidence from listed companies on Istanbul Stock Exchange (ISE). Investment Management and Financial Innovations, 3(2), 197-216.

Central Accountability Agency. (2008). The Egyptian standards for auditing and other assurance services. Retrieved from http://asa.gov.eg/Attach/274_Egyptian_Auditing_standards.PDF (In Arabic)

Chan, K., Lin, K., \& Zhang, F. (2007). On the association between changes in corporate ownership and chances in auditor quality in a transitional economy. Journal of International Accounting Research, 6(1), 19-36.

Chau, G., \& Leung, P. (2006). The impact of board composition and family ownership on audit committee formation: evidence from Hong Kong. Journal of International Accounting, Auditing and Taxation, 15, 1-15.

Chau, G., \& Gray, S. (2010). Family ownership, board independence and voluntary disclosure from Hong Kong. Journal of International Accounting, Auditing and Taxation, 19, 93-109.

Chen, T., Dong, H., \& Lin, C. (2017). Institutional ownership and audit quality: Evidence from Russell index reconstitutions. Retrieved from http://ssrn.com/abstract=2849685

Cheng, H., Huang, D., \& Luo, Y. (2018). Corporate disclosure quality and institutional investors' holdings during market downturns. Retrieved from http://ssrn.com/abstract=3248246

Choi, S., \& Seo, J. (2008). Institutional ownership and accounting transparency. Asia-Pacific Journal of Financial Studies, 37(4), 627-673.

Chung, K., \& Zhang, H. (2011). Corporate Governance and Institutional Ownership. Journal of Financial and Quantitative Analysis, 46(1), 247-273.

Cinko, M., \& Kasaboglu, O. (2017). A study of the relationship between institutional ownership and capital structure: Evidence from Turkey. Marmara Journal of Economics, 1(2), 155-170.

Dhaliwal, D., Li, S., Tsang, A., \& Yang, Y. (2011). Voluntary nonfinancial disclosure and the cost of equity capital: the initiation of corporate social responsibility reporting. The Accounting Review, 86(1), 59-100.

Egyptian Financial Supervisory Authority (EFSA). (2011). Rules of listing and delisting securities in Egyptian Stock Exchange, Rule No.31, Cairo. (In Arabic).

Egyptian Financial Supervisory Authority (EFSA). (2016a). Rules of listing and delisting securities in Egyptian Stock Exchange, Rule No.11, Cairo. (In Arabic).

Egyptian Financial Supervisory Authority (EFSA). (2016b). Egyptian Code of Corporate 
Governance (ECCG), Third release. Egyptian Institute of Directors (EIOD), Egypt. Retrieved from www.eiod.org

Elgammal, M., Hussainey, K., \& Ahmed, F. (2018). Corporate Governance and Voluntary Risk and Forward-looking Disclosures. Journal of Applied Accounting Research, 19(4), 592-607.

Ewart, J., Ford, J., \& Lin, C. (1982). Applied managerial statistics. Prentice - Hall, Inc.

Fan, J., \& Wong, T. (2005). Do external auditors perform a corporate governance role in emerging markets? Evidence from East Asia. Journal of Accounting Research, 43(1), 35-72.

Hossain, M., Marks, B., \& Mitra, S. (2006). Stock ownership structure and voluntary disclosure of quarterly foreign sales data of U.S. multinational corporations. The Multinational Business Review, 14(3), 71-93.

Hsu, C., Lai, S., \& Li, H. (2016). Institutional ownership and information transparency: Role of technology intensities and industries. Asia Pacific Management Review, 21, 26-37.

Huafang, X., \& Jianguo, Y. (2007). Ownership structure, board composition and corporate voluntary disclosure: Evidence from listed companies in China. Managerial Auditing Journal, 22(6), 604-619.

Hussainey, K., \& Al-Najjar, B. (2011). Future-oriented narrative reporting: determinants and use. Journal of Applied Accounting Research, 12(2), 123-138.

Jiang, H. (2009). Three essays on ownership concentration in New Zealand. A Ph.D. thesis in Accounting, Lincoln University, New Zealand.

Jiang, H., Habib, A., \& Hu, B. (2011). Ownership concentration, voluntary disclosures and information asymmetry in New Zealand. The British Accounting Review, 43(1), 39-52.

Johari, J., Devi, S., \& Ramachandra, S. (2016). Ownership and Segment disclosure: Moderating effect of competitiveness in Malaysia. Malaysian Accounting Review, 15(1), 225-249.

Jung, K., \& Kwon, S. (2002). Ownership structure and earnings informativeness: Evidence from Korea. The International Journal of Accounting, 37, 301-325.

Krause, J., Sellhorn, T., \& Ahmed, K. (2017). Extreme Uncertainty and Forward-looking Disclosure Properties. ABACUS, 53(2), 240-272.

Liu, S. (2015). Corporate governance and forward-looking disclosure: Evidence from China. Journal of International Accounting, Auditing and Taxation, 25, 16-30.

Mathuva, D. (2012). The determinants of forward-looking disclosures in interim reports for non-financial firms: Evidence from a developing country. International Journal of Accounting and Financial Reporting, 2(2), 125-141.

Mazumder, M. (2016). Exploring the impact of ownership structure on earnings predictability: Insights from Japan- Indian. Journal of Corporate Governance, 9(2), 97-121. 


\section{MInstitute ${ }^{\text {Mink }}$}

International Journal of Accounting and Financial Reporting

ISSN 2162-3082

2019, Vol. 9, No. 4

Mehrani, S., Moradi, M., \& Eskandar, H. (2017). Institutional ownership type and earnings quality: evidence from Iran. Emerging Markets Finance \& Trade, 53, 54-73.

Menicucci, E. (2013).The determinants of forward-looking information in management commentary: Evidence from Italian listed companies. International Business Research, 6(5), $30-44$.

Mousa, G., \& Elamir, E. (2018). Determinants of forward-looking disclosure: evidence from Bahraini capital market. Afro-Asian J. Finance and Accounting, 8(1), 1-19.

Qu, W., Ee, M., Liu, L., Wise, V., \& Carey, P. (2015). Corporate governance and quality of forward-looking information: Evidence from the Chinese stock market. Asian Review of Accounting, 23(1), 39-67.

Saad Eldeen, E. (2014). A proposed forward-looking financial information framework and testing it from investors' vision in stock market - A field Study. Commercial and Finance Scientific Journal, 2(1), 277-324. (in Arabic)

Sahin, M. (2011). The impact of institutional ownership and board structure on earnings management and acquisition performance of S\&P 500 index firms around their addition to the index and an experimental approach to buyer's brokerage. PhD Thesis, University of Connecticut.

Sakaki, H., Jackson, D., \& Jory, S. (2017). Institutional ownership stability and real earnings management. Review Quantitative Finance and Accounting, 49, 227-244.

Samaha, K., \& Dahawy, K. (2011). An empirical analysis of corporate governance structures and voluntary corporate disclosure in volatile capital markets: The Egyptian experience. International Journal of Accounting, Auditing and Performance Evaluation (IJAAPE), 7(1/2), 61-93.

Shiri, M., Salehi, M., \& Radbon, A. (2016). A Study of impact of ownership structure and disclosure quality on information asymmetry in Iran. The Journal for Decision Makers, 41(1), 51-60.

Soliman, M. (2013). Firm characteristics and the extent of voluntary disclosure: The case of Egypt. Research Journal of Finance and Accounting, 4(17), 71- 80.

Tsouknidis, D. (2019). The effect of institutional ownership on firm performance: the case of U.S. listed shipping companies. Maritime Policy \& Management, 46(5), 509-528.

Velury, U., \& Jenkins, D. (2006). Institutional ownership and the quality of earnings. Journal of Business Research, 59, 1043-1051.

Yasser, Q., Al Mamun, A., \& Ahmed, I. (2016). Quality of financial reporting in the Asia-Pacific region the influence of ownership composition. Review of International Business and Strategy, 26(4), 543-560.

Zhang, L., \& Ding, S. (2006). The effect of increased disclosure on cost of capital: Evidence from China. Review of Quantitative Financial Accounting, 27, 383-401. 


\section{Macrothink}

International Journal of Accounting and Financial Reporting

ISSN 2162-3082

2019, Vol. 9, No. 4

Zureigat, Q. (2011). The effect of ownership structure on audit quality: evidence from Jordan. International Journal of Business and Social Science, 2(10), 38-46.

\section{Note}

Note 1. During nineties, EGX comprised two stock markets located in Cairo and Alexandria and managed by the same Chairman and Board of Directors (CASE). Currently there is only one stock market located in Cairo.

\section{Appendix}

\section{Appendix A: Index of future information disclosure}

\section{1-Firm Strategy and Objectives}

- Firm mission and vision

- Main goals and future strategy to attain them

- The main markets and firm's competitive position

- Expected growth in firm's market share

- Main obstacles and plans to overcome them.

- New products/services development.

\section{2- Future Financial Information}

- Sales and income forecast

- Planned R\&D expenditure

- Forecasted cash flows

- Future capital expenditure

- Targeted share price

- Expected increase in EPS

- Forecasted financial indicators ( e.g. ROA, ROE)

- Returns from new investments and opportunities.

\section{3- Future Non - Financial Information}

- Future investment plan

- Future agreements and contracts 


\section{Macrothink \\ International Journal of Accounting and Financial Reporting \\ ISSN 2162-3082 \\ 2019, Vol. 9, No. 4}

- Risk management for future investment

- Operational plans for future period

- Impact of currency floating on future results

- Accounting methods and assumptions considered in future results

- Risks about financial forecasts and their effect on performance

- Information about human resources

- Effect of competition on future performance

\section{Copyright Disclaimer}

Copyright for this article is retained by the author(s), with first publication rights granted to the journal.

This is an open-access article distributed under the terms and conditions of the Creative Commons Attribution license (http://creativecommons.org/licenses/by/4.0/) 